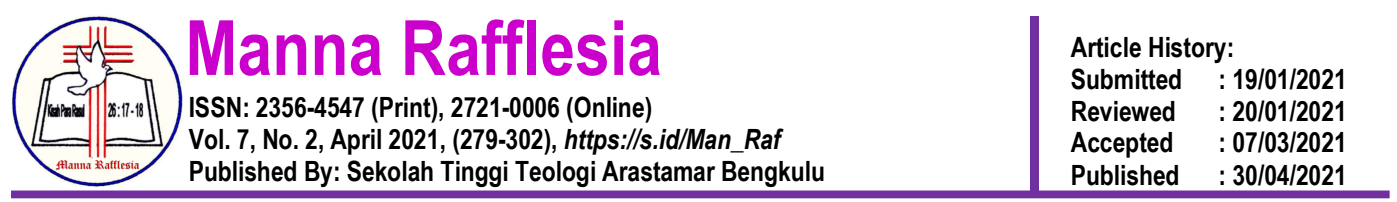

\title{
PENERAPAN KEPEMIMPINAN PASTORAL YESUS KRISTUS DALAM KITAB INJIL BAGI SEKOLAH TINGGI TEOLOGI PELITA DUNIA
}

\author{
Adi Putra, $\left.{ }^{1 *}\right)$ Gunar Sahari ${ }^{2}$ \\ Sekolah Tinggi Teologi Pelita Dunia ${ }^{12}$ \\ *)Email Correspondence: addiepoetra7@gmail.com
}

\begin{abstract}
This research discusses the pastoral leadership of Jesus Christ as written in the Gospels, to be further applied in the Curriculum of Pelita Dunia Theological Seminary (Ind. STT Pelita Dunia). So that every graduate produced can understand and practice correct pastoral leadership by the teachings and actions of Jesus Christ. This study uses a qualitative approach that combines a literature review with the results of interviews with several alumni. Through this research, information is obtained that Jesus' pastoral leadership based on the explanations in the Gospels is visible in three ways, such as Jesus' pastoral's leadership in carrying out God's vision, Jesus' pastoral's leadership reaching out to the lost, and improving relationships and pastoral's leadership. Jesus disciples and sent. This study also concluded that STT Pelita Dunia needs to include and teach Pastoral Leadership to every student to produce graduates who can serve like Jesus.
\end{abstract}

Keywords: $\quad$ Pastoral Leadership, Jesus Christ, Curriculum, Pelita Dunia Theological Seminary.

Abstrak: $\quad$ Penelitian ini membahas tentang kepemimpinan pastoral Yesus Kristus seperti yang tertulis dalam kitab Injil, untuk selanjutnya diterapkan dalam Kurikulum Sekolah Tinggi Teologi Pelita Dunia (STT Pelita Dunia). Sehingga setiap lulusan yang dihasilkan dapat memahami dan mempraktikkan kepemimpinan pastoral yang benar sesuai dengan ajaran dan tindakan Yesus Kristus. Penelitian ini menggunakan pendekatan kualitatif yang mengkombinasikan kajian pustaka dengan beberapa hasil wawancara dengan beberapa alumni. Melalui penelitian ini diperoleh informasi bahwa pastoral leadership Yesus berdasarkan penjelasan dalam Injil terlihat dengan jelas dalam tiga hal, seperti: pastoral leadership Yesus menjalankan visi Allah, pastoral leadership Yesus menjangkau yang hilang dan memperbaiki relasi dan pastoral leadership Yesus memuridkan dan mengutus. Selain itu, penelitian ini juga menyimpulkan bahwa STT Pelita Dunia perlu memasukkan dan mengajarkan Pastoral Leadership kepada setiap mahasiswa guna menghasilkan lulusan yang dapat melayani seperti Yesus.

Kata Kunci: Kepemimpinan Gembala, Yesus Kristus, Kurikulum, STT Pelita Dunia.

\section{PENDAHULUAN}

Kepemimpinan Pastoral (pastoral leadership) bukan hanya sekadar materi

perkuliahan. Melainkan sebuah materi yang bermanfaat membentuk ciri dan cara kepemimpinan setiap pelayan dalam mengerjakan misi Allah di tengah-tengah dunia ini. Seperti yang telah diketahui bahwa pemimpim Kristen harusnya 
mempraktikkan kepemimpinan yang mengimitasi prinsip dan cara-cara yang telah ditunjukkan oleh Yesus Kristus. Agus Purwanto mengatakan, "Kepemimpinan Kristen dapat diartikan sebagai sebuah model Kepemimpinan yang dilakukan dengan mendasarkan pada prinsip-prinsip atau keteladanan kepemimpinan yang telah diajarkan oleh Yesus Kristus. Pemimpin Kristen adalah pemimpin yang menjalankan kepemimpinannya berdasarkan ajaran-ajaran dan keteladanan kepemimpinan Yesus Kristus.”" Hal inilah yang kurang dipahami oleh banyak Sekolah Tinggi Teologi (STT) ketika merumuskan dan menyusun kurikulumnya.

David Wayne Christine mengatakan, "A quick overview of curriculum and catalogues of Bible colleges and seminaries show an increase in the number and diversity of courses dealing with pastoral leadership within the last 20 years."2 Menurut Christine ada kecenderungan peningkatan dalam jumlah dan keragaman jurusan yang berhubungan dengan kepemimpinan pastoral dalam 20 tahun terakhir. Sekalipun demikian, Themes berkomentar, "One prominent seminary devotes less than $9 \%$ of its courses to pastoral leadership." ${ }^{3}$ Menurutnya, ada sebuah seminari teologi terkemuka yang hanya mengalokasikan 9\% mata kuliah untuk pastoral leadership. Padahal tempat terbaik untuk menciptakan pemimpin agama dalam konteks kekristenan adalah di seminari teologi. Robert Greenleaf memberikan komentar bahwa tempat terbaik untuk menghasilkan pemimpin agama adalah di seminari. Namun, agar hal ini terjadi, seminari harus menentukkan prioritasnya, bahkan bagi Greeleaf, seminari sekarang sebagian

\footnotetext{
${ }^{1}$ Agus Purwanto, "Kepemimpinan Yesus Kristus sebagai Model Kepemimpinan Kristen," Mathetes: Jurnal Teologi dan Pendidikan Kristen 1, no. 2 (2020): 131-46. https://sttbethelsamarinda.ac.id/ejournal/index.php/mathetes/article/view/17/18

2 David Wayne Christine, "Baptist Pastoral Leadership: An Analysis for Curriculum Development" (University of North Texas, 2010), 15.

${ }^{3}$ Christine., 16.
} 
besar bersifat akademis dan hanya bersifat formatif, pembentukan pemimpin agama akan menjadi yang utama dan pengajaran akademis akan menjadi sekunder. ${ }^{4}$ Secara tidak langsung pendapat Greenleaf hendak mengemukakan bahwa Sekolah Tinggi Teologi memiliki kewajiban yang lebih besar untuk menghasilkan pemimpin dalam gereja dari pada hanya sekadar mendidik sarjana teologi. Christine mengemukakan bahwa pada tahun 2005 Harvard Divinity School telah merevisi kurikulum sebagai tanggapan atas kritik, bahwa sekolah tersebut lebih fokus pada penciptaan sarjana akademis daripada perkembangan pelayanan penggembalaan. $^{5}$

Kondisi yang telah dikemukakan di atas ternyata juga terjadi dalam lingkup akademis STT Pelita Dunia. Apabila memperhatikan lulusan yang telah dihasilkan, maka ada kendala perihal alumni yang dihasilkan. Di mana mayoritas alumni belum menunjukkan indikator-indikator pastoral leadership dalam pelayanan. Ada beberapa alumni yang kesulitan dalam mendapatkan tempat pelayanan dan ada pula yang belum punya komitmen yang teguh dalam pelayanan. Sehingga ada beberapa alumni yang pindah-pindah tempat pelayanan dengan alasan tempatnya tidak cocok dan tempatnya kurang nyaman.

Berdasarkan kondisi ini dilakukan wawancara terhadap beberapa alumni, dengan mengajukan pertanyaan tentang apa itu pastoral leadership? Maka mayoritas jawaban masih bersifat normatif. Pertama, seperti seorang gembala yang menggembalakan kawanan domba-dombanya dan menghimpunkannya dengan tangannya anak-anak domba dipangkunya, induk-induk

4 Robert Greenleaf, The Power of Servant Leadership (San Francisco: CA. Berrett-Koehler Publications Inc., 1998).

${ }^{5}$ Christine, "Baptist Pastoral Leadership: An Analysis for Curriculum Development." 
domba dituntun-Nya dengan hati-hati. ${ }^{6}$ Kedua, mengarah kepada kepemimpinan atau memuridkan, menjaga, mengarahkan jemaat secara rohani. ${ }^{7}$ Ketiga, mungkin tentang bagaimana menjadi seorang pastor atau gembala yang jiwa pemimpin seperti Kristus Yesus yang adalah gembala sejati dan pemimpin yang sejati. ${ }^{8}$ Keempat, tentang kepemimpinan seorang hamba Tuhan. ${ }^{9}$ Kelima, pastoral leadership adalah Seorang pemimpin yang melaksanan pelayan penggembalaan kepada jemaat dalam sebuah organisasi atau jemaat lokal. ${ }^{10}$ Mengamati jawaban yang diberikan oleh beberapa alumni di atas menunjukkan memang tidak ada masalah, akan tetapi jawaban-jawaban di atas cenderung normatif. Sehingga menjadi masuk akal apabila mayoritas alumni kurang memahami substansi dari pastoral leadership.

Mengamati kurikulum STT Pelita Dunia saat ini tidak termaktub mata kuliah pastoral leadership (kepemimpinan pastoral). Sekalipun ada 2 sks (satuan kredit semester) untuk mata kuliah Pastoral dan 2 sks juga untuk mata kuliah lepemimpinan dan tidak ada mata kuliah pastoral leadership. Kondisi ini memang mempengaruhi lulusan, padahal setelah lulus mereka langsung diutus masuk dalam dunia pelayanan dan memimpin jemaat Tuhan. Masalah inilah yang diteliti dalam penelitian ini.

Dalam mengkaji Kitab Injil penulis menemukan pembahasan tentang dasar teori dan sumber prinsip kepemimpinan pastoral Yesus Kristus. Temuan tersebut menjadi sebuah usulan pengajaran kepemimpinan pastoral. Setelah itu dilanjutkan dengan kajian terhadap kondisi kurikulum STT Pelita Dunia,

\footnotetext{
${ }^{6}$ Esti R. Boiliu, Apa itu pastoral leadership?, Alumni STT Pelita Dunia, 19 Januari 2021.

7 Kasiria Laia, Apa itu pastoral leadership?, Alumni STT Pelita Dunia, 19 Januari 2021.

8 Fridolin Rumlawang, Apa itu pastoral leadership?, Alumni STT Pelita Dunia, 19 Januari 2021.

${ }^{9}$ Elvis Telaumbanua, Apa itu pastoral leadership?, Alumni STT Pelita Dunia, 19 Januari 2021.

10 Fenci Fallo, Apa itu pastoral leadership?, Alumni STT Pelita Dunia, 19 Januari 2021.
} 
kemudian mengkaji penerapan kepemimpinan gembala Yesus dalam kurikulum STT Pelita Dunia. Diharapkan penelitian ini memberikan sebuah masukan yang konstruktif kepada bagi STT Pelita Dunia untuk melakukan pembenahan kurikulum guna menunjang dihasilkannya alumni yang memahami dan menerapkan pastoral leadership yang benar dan alkitabiah dalam pelayanan.

\section{METODE}

Penelitian ini menggunakan metode kualitatif. The SAGE Encyclopedia of Qualitative Research Methods mengatakan metode kualitatif paling baik untuk menangani banyak dari pertanyaan yang ada dalam pikiran peneliti. Ditambahkan oleh pendapat di atas, pendekatan kualitatif digunakan untuk mengeksplorasi fenomena baru dan menangkap pikiran, perasaan, atau interpretasi individu tentang makna dan proses. ${ }^{11}$ Kemudian dalam buku The Oxford Handbook of Qualitative Research dikemukakan, penelitian kualitatif membutuhkan kerja sama dengan orang lain selama rentang waktu tertentu dan memproduksi sejumlah besar data untuk analisis, sekaligus menuntut perhatian berkelanjutan terhadap etika dan nilai. Dengan demikian penelitian kualitatif adalah proses kreatif yang membuat peneliti bereksperimen, bermain, beradaptasi, belajar dan bertumbuh. ${ }^{12}$

Penelitian ini mengkombinasikan antara tinjauan pustaka yang diolah secara kreatif dengan data atau informasi dari responden yang dipadukan menjadi sebuah data kualitatif yang kredibel. John Creswell mengatakan, "Tinjauan kepustakaan adalah rangkuman tertulis dari berbagai artikel jurnal, buku dan dokumen-dokumen lain yang mendeskripsikan situasi, informasi sebelumnya dan

11 Lisa M. Given, ed., The SAGE Encyclopedia of Qualitative Research Methods Volume 1 \& 2 (New Delhi, India: SAGE Publication, 2008), xxix.

12 Patricia Leavy, ed., The Oxford Handbook of Qualitative Research (New York: Oxford University Press, 2014), 6. 
saat ini tentang topik penelitian." 13 Dengan demikian diharapkan setiap kesimpulan yang diperoleh dari penelitian ini merupakan kesimpulan yang telah teruji dalam konteks penelitian kualitatif. Pendekatan kualitatif di sini mengandalkan data atau informasi dari hasil penelitian atau buku-buku yang memiliki cakupan penelitian yang sama, bahkan termasuk informasi-informasi hasil kuesioner dan wawancara dengan beberapa responden yang merupakan alumni dari STT Pelita Dunia.

\section{HASIL}

Pada penelitian ini, ditemukan adanya masalah yang urgen perihal alumni STT Pelita Dunia untuk memahami dan mengerti kepemimpinan gembala yang diajarkan dan dipraktikkan oleh Yesus Kristus. Sehingga mereka dapat mempraktikkannya dalam pelayanan yang dipercayakan. Melalui penelitian ini diperoleh beberapa poin yang berkaitan hasil penelitian. Pertama, melalui pendekatan kualitatif yang menekankan kepada sebuah kajian pustaka maka ditemukan beberapa prinsip dan penekanan dalam kepemimpinan gembala yang diajarkan dan dipraktikkan oleh Yesus, seperti: kepemimpinan gembala Yesus Kristus adalah kepemimpinan gembala yang mengerjakan visi Bapa, kepemimpinan gembala Yesus Kristus adalah kepemimpinan gembala yang mencari yang hilang dan memperbaiki relasi, dan kepemimpinan gembala Yesus Kristus adalah kepemimpinan gembala yang memuridkan dan mengutus. Kedua, melalui penelitian ini pula ditemukan bahwa pada struktur kurikulum STT Pelita Dunia perlu ditambahkan mata kuliah Pastoral Leadership (Kepemimpinan Gembala) guna melengkapi dua mata kuliah yang identik, yakni: Kepemimpinan 
Kristen dan Pastoral. Sehingga dengan dimasukkannya mata kuliah tersebut maka dapat menghasilkan alumni yang dapat mempraktikkan kombinasi kepemimpinan Kristen dan juga Pastoral dalam bingkai praktik dan pengajaran Yesus Kristus seperti yang termaktub dalam kitab Injil.

\section{PEMBAHASAN}

Pada bagian ini memeberikan fokus pembahasan tentang prinsip pastoral leadership Yesus Kristus, kondisi kurikulum STT Pelita Dunia dan penerapan pastoral leadership Yesus Kristus bagi STT Pelita Dunia.

\section{Pastoral Leadership Yesus Dalam Kitab Injil}

Kepemimpinan Pastoral atau pastoral leadership secara teori harus didasarkan kepada fakta dan penjelasan Alkitab, terutama kepemimpinan gembala yang telah dilakukan dan dicontohkan oleh Yesus. Juliana Panjaitan menuliskan bahwa dalam Perjanjian Baru Yesus diibaratkan sebagai gembala yang baik dan telah memberikan teladan hidup bagi domba-domba-Nya. Yesus tidak hanya memperkuat pengajarannya saja, namun teladan hidpunya yang mampu membuat banyak orang mengikuti-Nya. ${ }^{14}$ Selanjutnya Romerlito C. Macalinao menuliskan, teori kepemimpinan di Gereja diambil dari tiga sumber, yaitu: kehidupan dan pelayanan Yesus Kristus, tema-tema alkitabiah dan teori manajemen. Beberapa penulis telah memberikan penekanan pada kehidupan dan pelayanan Yesus Kristus sebagai paradigma kepemimpinan. ${ }^{15}$

\footnotetext{
14 Juliana Panjaitan, "Pengaruh kepemimpinan Gembala sidang terhadap pertumbuhan gereja masa kini," 2020.

${ }^{15}$ Romerlito C. Macalinao, "Study of The Leadership Attributes of Pastors In Large Churches In Urban Metro Manila and The Implications to Designing A Pastoral Leadership Development Program" (Asia Graduate School of Theology, 2004), 44-45.
} 
Philip Greenslade mengidentifikasi gaya kepemimpinan Yesus seperti yang dikutip oleh Macalinao bahwa dalam kepemimpinan, beberapa peran kepemimpinan berasal dari kehidupan Kristus seperti, menjadi seorang Bapa, ahli bangunan, pembuka mata, instruktur, pelatih, pemecah masalah, penjaga / pelindung dan perintis. ${ }^{16}$ Sedangkan Youssef mengomentari tentang gaya kepemimpinan Yesus bahwa gaya kepemimpinan Yesus terlihat dari kualitas kepemimpinan, seperti: keberanian, kelembutan, kemurahan hati, kejujuran, dan pengampunan serta memasukkan beberapa godaan kepemimpinan seperti kekuatan, ego dan kemarahan. Youssef mencatat bahwa keraguan dan kritik adalah beberapa masalah serta bagaimana mengubah pengikut menjadi pemimpin. ${ }^{17}$ Beasley-Murray dalam buku Dynamic Leadership menuliskan: kepemimpinan pastoral dibangun dari kehidupan Kristus, tentang kebutuhan gereja akan pemimpin dan kebutuhan akan kepemimpinan dengan pendekatan. Salah satu atribut unik dari karya Kristus adalah penekanan pada tim dan kepemimpinan tim. ${ }^{18}$

Sedangkan Leighton Ford, dalam buku Transforming Leadership mengemukakan tentang empat dasar kepemimpinan dari Warren Bennis, yaitu visi, komunikasi, kepercayaan dan pemberdayaan yang dimiliki semua oleh Yesus Kristus. ${ }^{19}$

Berdasarkan uraian beberapa ahli di atas maka ditemukan betapa urgen dan sentral posisi kepemimpinan pastoral Yesus yang dikemukakan dalam kitab Injil. Mengenai hal tersebut Natanael S. Prajogo menuliskan bahwa dalam masa

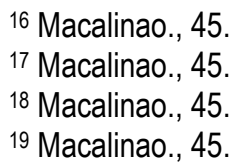


hidup Yesus Kristus di Bumi sebagai Sang Pemimpin Agung Yesus memperkenalkan, mengajarkan dan mempraktikkan sebuah model kepemimpinan yang menginspirasi para pemimpin dunia sampai sekarang. Itulah model kepemimpinan yang melayani (Mat. 20: 20-28; Mrk. 10: 35-41). ${ }^{20}$ Senada dengan itu Yohanes Parapat menuliskan bahwa keberhasilan kepemimpinan Yesus dilihat dari sisi suksesi kedua belas murid atau rasul, khususnya dalam hal pertumbuhan jumlah orang percaya (Kis. 2: 41, 4: 4, 5: 14, 6: 7, 8: 6, 9:3, 42). Dengan demikian dalam konteks kepemimpinan Yesus, penambahan jumlah orang percaya merupakan visi yang ditetapkan-Nya untuk dicapai oleh para murid, dalam Matius 28:18-20 dikenal sebagai amanat agung, yaitu menjadikan segala bangsa murid-Nya. ${ }^{21}$

Ada beberapa prinsip dan ciri dari kepemimpinan gembala (pastoral leadership) Yesus, yaitu:

\section{Mengerjakan Visi Bapa-Nya}

Yesus datang ke dalam dunia karena diutus oleh Bapa-Nya untuk menjalankan misi Allah (missio dei) menyelamatkan manusia yang berdosa (Lih. Yoh. 5: 23; 6: 57; 7: 29). Misi tersebut memberikan sebuah indikator bahwa Yesus datang ke dalam dunia karena diutus oleh Bapa dan itu artinya Dia membawa dan mengerjakan visi Bapa-Nya. Donald Guthrie memberikan komentar perihal Yohanes 5:23 bahwa cara Yesus menggunakan gelar Anak berasal dari kebiasaan-Nya memanggil Allah, Bapa-Nya. Hal ini menunjukkan

20 Natanael S Prajogo, "Implementasi kepemimpinan gembala yang melayani berdasarkan 1 Petrus 5: 2-10 di kalangan gembala jemaat Gereja Bethel Indonesia se-Jawa Tengah," Harvester: Jurnal Teologi dan Kepemimpinan Kristen 4, no. 1 (2019): 1-21. https://doi.org/10.52104/harvester.v4i1.5

21 Yohanes Parapat, "Fungsi Gembala Jemaat dalam Suksesi-Refleksi atas Kepemimpinan Yesus pada Model Gereja Otonomi," Harvester: Jurnal Teologi dan Kepemimpinan Kristen 5, no. 2 (2020): 73-85. https://doi.org/10.52104/harvester.v5i2.43 
hubungan yang sangat akrab. Yesus memberikan empat alasan untuk mendukung klaimnya, yaitu: Pertama, Anak bertindak tepat seperti Bapa (19), kedua, kepada Anak, Bapa menyatakan rencana-Nya (20), ketiga, seperti Bapa, Anak berkuasa memberi hidup (21) dan keempat Bapa memberi otoritas kepada Anak untuk menghakimi (23). ${ }^{22}$ Selanjutnya Colin G. Kruse menjelaskan Yohanes 7:29 bahwa Yesus menyatakan bahwa Ia diutus oleh Allah yang benar, yang ditunjukkan dengan penggunaan kata Yunani alethinos. ${ }^{23}$

Yesus telah mempraktikkan sebuah kepemimpinan gembala yang ideal. Di mana visi yang dikerjakannya adalah visi dari Surga, yaitu visi Bapa-Nya. Dia tidak mengutamakan kepentingan pribadi-Nya. Bahkan Dia telah memperlihatkan sebuah ketaatan total kepada Bapa melalui pelayanan-Nya di bumi. Dia mengajarkan tentang Kerajaan Allah, mengkhotbahkan tentang Kerajaan Allah dan menyembuhkan berbagai penyakit juga menggunakan kuasa Kerajaan Allah. Dengan demikian setiap pemimpin dalam jemaat tidak membawa visi pribadi dalam pelayanan dan menggembalakan jemaat. Oleh karena jemaat itu milik Allah maka pengajaran yang diberikan berdasarkan firman Tuhan (Alkitab) bukan pemikiran dan pengalaman gembala.

\section{Mencari yang hilang dan Memperbaiki Relasi dengan Allah}

Kepemimpinan gembala yang dilakukan dan ditunjukkan oleh Yesus adalah mencari yang hilang dan memperbaiki relasi dengan Allah (Lih. Luk. 19: 10). Yesus menegaskan titik kulminasi pelayanan-Nya ketika menderita, disalibkan, mati dan bangkit pada hari ketiga. Semua dilakukan Yesus untuk

22 G.J. Wenham. D.A. Carson, R.T. France, J.A. Motyer, ed., Tafsiran Alkitab Abad Ke-21 (MatiusWahyu) (Jakarta: YKBK/OMF, 2017), 184. 2007), 188-189.

${ }_{23}$ Colin G. Kruse, The Tyndale New Testament Commentaries: John (Surabaya: Momentum, 
memperbaiki relasi yang telah rusak antara Allah dan manusia. Lukas 19:10 merupakan ending dari kisah tentang Zakheus, yang merupakan pemungut cukai dan dianggap orang yang paling berdosa tetapi kemudian bertobat ketika berjumpa dengan Yesus. Ayat 10 merupakan potongan dari ungkapan Yesus dari ayat 9 sebagai respons-Nya terhadap pertobatan yang dialami oleh Zakheus. Leon Morris memberikan komentarnya bahawa Yesus datang untuk menyelamatkan yang hilang, Yesus mencari Zakheus seorang di antara manusia yang terhilang, tetapi Yesus tidak meninggalkan namun menyelematkan Zakheus. ${ }^{24}$ I. Howard Marshall menuliskan tujuan kedatangan Yesus disimpulkan sepenuhnya: seperti seorang gembala yang pergi mencari domba yang hilang untuk menyelamatkannya dari bahaya, demikianlah Yesus sebagai Anak Allah mencari dan menyelamatkan orang yang hilang". 25

Selain mengerjakan visi Allah, Yesus juga mencari dan menyelamatkan yang hilang. Sehingga hubungan yang rusak karena telah melakukan dosa diperbaiki dan manusia kembali dapat memiliki persekutuan dengan Allah. Tentunya, ini merupakan sebuah praktik kepemimpinan pastoral yang ideal dan perlu dicontoh serta diterapkan oleh pemimpin jemaat masa kini. Dengan demikian pemimpin jemaat perlu memperhatikan seluruh kondisi jemaat. Apabila dijumpai ada yang terhilang dan terjerumus dalam perbuatan-perbuatan dosa, maka tugas gembala adalah merangkul, mengajar dan mengambalikannya kepada kehidupan yang benar melalui pembinaan dan pengajaran Alkitab. Gembala tidak diperbolehkan untuk membiarkan jemaat yang jatuh dalam dosa untuk terus299.

24 Leon Morris, The Tyndale New Testament Commentaries: Luke (Surabaya: Momentum, 2007), 25 D.A. Carson, R.T. France, J.A. Motyer, Tafsiran Alkitab Abad Ke-21 (Matius-Wahyu), 184. 
menerus melakukan dosa, terlebih berkompromi dengan orang-orang yang masih sering melakukan dosa.

\section{Memuridkan dan Mengutus}

Kepemimpinan gembala Yesus yang ketiga adalah kepemimpinan yang memuridkan dan mengutus. Ketika memulai pelayanan-Nya di bumi, Yesus memilih beberapa orang menjadi murid-Nya. Mereka dipilih dan dipanggil secara khusus untuk menjadi penjala manusia. Akan tetapi sebelum mereka diutus menjadi penjala manusia, mereka terlebih dahulu dimuridkan oleh Yesus supaya mereka mengerti dan memahami kehendak Bapa di Surga. Supaya mereka pun dapat mengerjakan hal yang sama yang telah dikerjakan oleh Yesus, yakni: mengerjakan misi Bapa di Surga. Matius 4: 19 adalah ungkapan Yesus yang mengindikasikan betapa penggembalaan Yesus adalah memuridkan dan mengutus. Richard T. France menuliskan para pengikut Yesus tidak hanya menjadi pendukung, tetapi menjadi penjala manusia dan memenangkan warga baru ke dalam pemerintahan Allah. ${ }^{26}$

Demikian juga halnya ketika Yesus sebelum terangkat ke Surga (paskakebangkitan-Nya) dalam Matius 28: 19-20 yang biasa dikenal dengan Amanat Agung. Berdasarkan Amanat Agung ini, dapat dilihat sebuah pola yang menarik. Di mana Yesus setelah memuridkan para murid-Nya, maka sekarang tibalah saatnya Dia mengutus para murid untuk menjadikan semua bangsa murid-Nya. Menurut Leon Morris para murid bertugas menjadikan segala bangsa sebagai murid Yesus, jangkauan misi bersifat mendunia. Yesus kemudian berbicara tentang hal membaptis para murid baru dalam nama Bapa dan Anak dan Roh

${ }_{26}$ D.A. Carson, R.T. France, J.A. Motyer, 54. 
Kudus. Perlu diperhatikan nama di sini berbentuk tunggal; Yesus tidak berkata para pengikut-Nya harus dibaptis di dalam nama Allah, nama Anak, dan nama Roh Kudus, tetapi memakai bentuk tunggal nama di dalam semua ini. Hal ini menunjukkan dalam satu pengertian, ketiganya adalah satu. Para murid baru harus dibaptis, tetapi juga harus diajar melakukan segala sesuatu yang telah Kuperintahkan kepadamu. Karena itu, fungsi pengajaran jemaat teramat penting, karena Yesus memerintahkan untuk mengajar dan tidak bisa mengurangi arti penting dari aktivitas yang awalnya berasal dari perintah Tuhan sendiri. ${ }^{27}$

Yesus juga telah mempraktikkan kepemimpinan gembala yang memuridkan dan mengutus. Ini merupakan kepemimpinan gembala yang ideal. Karena sudah seharusnya setiap pemimpin jemaat juga melakukan hal yang sama. Gembala harus memuridkan jemaatnya dengan pengajaran-pengajaran rasuli atau alkitabiah. Sehingga melaluinya mereka mengerti kehendak Bapa dan menerapkannya dalam pelayanan dan kehidupan praktisnya. Setelah para murid mengerti kehendak Bapa dalam Tuhan Yesus, barulah diutus untuk pergi memberitakan Injil atau menjadikan semua bangsa murid Kristus. Dengan demikian dapat dilihat muara dari sebuah kepemimpinan gembala adalah pengutusan atau misi atau pemberitaan Injil. Sehingga gereja yang benar dan sehat, yang memiliki kepemimpinan gembala yang alkitabiah adalah gereja yang masih memberitakan Injil Kristus, yang didasarkan pada peristiwa kebangkitan Yesus.

Kepemimpinan gembala yang memuridkan dan mengutus identik dengan kepemimpinan gembala yang melayani dan mau menjadi hamba. Seperti yang

27 Leon Morris, Tafsiran Injil Matius (Surabaya: Momentum, 2016), 759-762. 
dikemukakan oleh Adriaan Wakkary bahwa Yesus menegur dan mengajarkan para murid untuk menjadi pemimpin yang melayani (Mrk. 9: 35). Tuhan ingin mengubah gaya kepemimpinan bahwa kebesaran yang sejati bukan karena suatu jabatan atau posisi, melainkan dari suatu sikap rendah hati yang dapat melayani semua orang bahkan yang paling rendah sekalipun (Mrk. 9: 36, 37). ${ }^{28}$ Dengan demikian, ketika Yesus mempraktikkan kepemimpinan gembala yang memuridkan dan mengutus, Dia juga menekankan bahwa bagian ini tidak dapat dipisahkan dari kepemimpinan yang melayani dan mau menjadi hamba. Oleh karena seorang murid yang diutus untuk memberitakan Injil harus sadar bahwa dia adalah hamba Kristus.

\section{Kondisi Kurikulum STT Pelita Dunia}

Pada bagian ini akan dideskripsikan perihal kondisi kurikulum STT Pelita Dunia terutama mata kuliah yang berkaitan dengan pastoral leadership (kepemimpinan gembala). Secara umum, kurikulum STT Pelita Dunia masih mengacu kepada buku kurikulum yang diterbitkan oleh Kementerian Agama RI, khususnya Bimas Kristen yakni buku Panduan Kurikulum Stratum Satu (S1) Prodi, Teologi Kependetaan Sekolah Tinggi Teologi dan Sekolah Tinggi Agama Kristen di Indonesia dan biasa disebut buku kuning. Berdasarkan buku tersebut, maka untuk program studi S1 Teologi (S.Th.) maupun S1 PAK (S.Pd.) tidak terdapat mata kuliah Kepemimpinan Gembala atau Pastoral Leadership. Sekalipun terdapat dua mata kuliah yang identik dengannya, yakni: Kepemimpinan Kristen dan Pastoral. Akan tetapi keduanya diajarkan terpisah, demikian juga di STT Pelita Dunia.

${ }^{28}$ Adriaan Wakkary, "Kepemimpinan Yesus," Rhema: Jurnal Teologi Biblika dan Praktika 3, no. 2 (2017). https://e-journal.stt-yestoya.ac.id/index.php/rhema/article/view/40/28 
Apabila memperhatikan buku kuning maka mata kuliah Kepemimpinan Kristen dan Pastoral termasuk ke dalam kelompok Mata Kuliah Perilaku Berkarya (MPB). Mata kuliah yang tergabung ke dalam kelompok ini merupakan sejumlah mata kuliah yang merupakan substansi keahlian terapan program pendidikan vokasi pada stratum tertentu. Kompetensinya yang diharapkan adalah: (1) Memiliki kemampuan profesional sebagai pelayan di gereja dan masyarakat; dan (2) Dapat menerapkan prinsip-prinsip kristiani dalam melaksanakan tugas. ${ }^{29}$ Dengan demikian kedua mata kuliah ini menjadi mata kuliah yang penting dan diperlukan oleh setiap mahasiswa sehingga kelak dapat melayani dengan profesional sebagai gembala atau pemimpin di gereja lokal. Berikut ini diuraikan rincian dari kedua mata kuliah di atas berdasarkan uraian dalam buku kuning.

\section{Kepemimpinan Kristen (2 sks)}

Standar Kompetensi (SK): Mahasiswa memiliki pengetahuan tentang kepemimpinan Kristen, menghayati prinsip-prinsipnya, serta menunjukkan kebiasaan berperilaku sesuai nilai-nilai yang terkandung di dalamnya.

Kompetensi Dasar (KD): pertama, mampu menjelaskan pengertian dan lingkup studi kepemimpinan, kedua, mampu menjelaskan konsep dasar kepemimpinan, ketiga, mampu mengidentifikasi pola-pola kepemimpinan, keempat, mampu mengemukakan aspek-aspek kepemimpinan, kelima, mampu menguraikan teologi kepemimpinan Kristen, keenam, mampu mengidentifikasi model-model kepemimpinan, ketujuh, mampu memahami model kepemimpinan Yesus, kedelapan, mampu menjelaskan nilai-nilai kepemimpinan Kristen, kesembilan, mempunyai semangat mengembangkan sumber daya kepemimpinan 
Kristen, dan ksepuluh, mampu menerapkan nilai-nilai kepemimpinan Kristen dalam pelayanan di gereja dan masyarakat.

Urutan dan Rincian Materi, pertama, pengertian dan Lingkup Kepemimpinan Kristen, kedua, konsep dasat Kepemimpinan, ketiga, pola-pola Kepemimpinan, keempat, aspek-aspek Kepemimpinan, kelima, teologi Kepemimpinan Kristen, keenam, model-model Kepemimpinan, ketujuh, model kepemimpinan Yesus Kristus, kedelapan, nilai-nilai kepemimpinan Kristen, dan kesembilan. pengembangan Sumber Daya Kepemimpinan Kristen.

\section{Pastoral (2 sks)}

Standar Kompetensi (SK): Mahasiswa memiliki pengetahuan dasar Alkitabiah tentang penggembalaan dan aspek-aspeknya, menyenangi kegiatan penggembalaan, dan dapat mendesain bentuk penggembalaan dalam pelayanan gerejawi yang kontekstual.

Kompetensi Dasar (KD): Pertama, mampu menjelaskan pengertian penggembalaan dan dasar-dasar alkitabiah tentang penggembalaan, kedua, mampu menunjukkan hubungan penggembalaan dengan tri-tugas gereja, ketiga, mampu mendeskripsikan penggembalaan sebagai wujud penggembalaan iman, keempat, mampu mengidentifikasi unsur-unsur dalam proses penggembalaan, kelima, mampu menunjukkan kualifikasi seorang gembala, keenam, mampu merancang langkah-langkah penggembalaan dalam konteks jemaat lokal, ketujuh, mampu mengidentifikasi hambatan dan tantangan dalam penggembalaan dan kedelapan, mampu mendesain kapita selekta penggembalaan.

Urutan dan Rincian Materi: pertama, pengertian penggembalaan dan dasar-dasar alkitabiah tentang penggembalaan, kedua, Tri tugas gereja dan 
hubungannya dengan penggembalaan, ketiga, penggembalaan sebagai wujud pemeliharaan iman, keempat, unsur-unsur dalam proses penggembalaan, kelima, kualifikasi seorang gembala, keenam, langkah-langkah penggembalaan, ketujuh, hambatan dan tantangan dalam penggembalaan, dan kedelapan, kapita selekta penggembalaan: perkunjungan dan percakapan pastoral, pengakuan dosa dan disiplin gerejani, seputar baptisan, peneguhan sidi dan perjamuan kudus, peneguhan nikah dan kesulitan perkawinan, kematian dan kedukaan, penggembala kepada: orang usia lanjut, sakit dan penggembalaan khusus (narapidana, berbagai kecanduan, dll.).

Berdasarkan pemaparan di atas, maka diperoleh beberapa data dan informasi sebagai hasil analisis dalam penelitian ini, yakni: pertama, ada kecenderungan dalam uraian Standar Kompetensi mata kuliah lebih menekankan apsek kognitif atau teoritis atau pengetahuan yang juga masih bersifat normatif. Kedua, ada kecenderungan dalam uraian Kompetensi Dasar mata kuliah berisi indikator-indikator yang juga cakupannya masih sangat luas (umum). Ketiga, ada kecenderungan dalam uraian Rincian dan Urutan Materi dari mata kuliah juga masih sangat umum dan normatif. Keempat, berdasarkan uraian dari SK, KD dan Rincian atau Urutan Materi, maka memberikan kecenderungan untuk menghasilkan lulusan memahami kepemimpinan dan pastoral secara umum dan normatif. Kelima, berdasarkan hasil analisis pada poin a,b,c,d, maka melalui penelitian ini diusulkan untuk menambahkan satu mata kuliah yang bisa dikatakan sebagai penggabungan mata kuliah Kepemimpinan Kristen dan Pastoral, di mana SK, KD, Urutan dan Rincian Materinya secara khusus merujuk kepada Kepemimpinan Gembala Yesus seperti yang termaktub pada pembahasan Pastoral 
Leadership Yesus dalam Kitab Injil. Mata kuliah ini nantinya akan diberi nama Pastoral Leadership. Dengan demikian, alumni STT Pelita Dunia akan memahami seperti apa dan bagaimana mempraktikkan pastoral leadership dalam pelayanan penggembalaan yang dikerjakan oleh mereka.

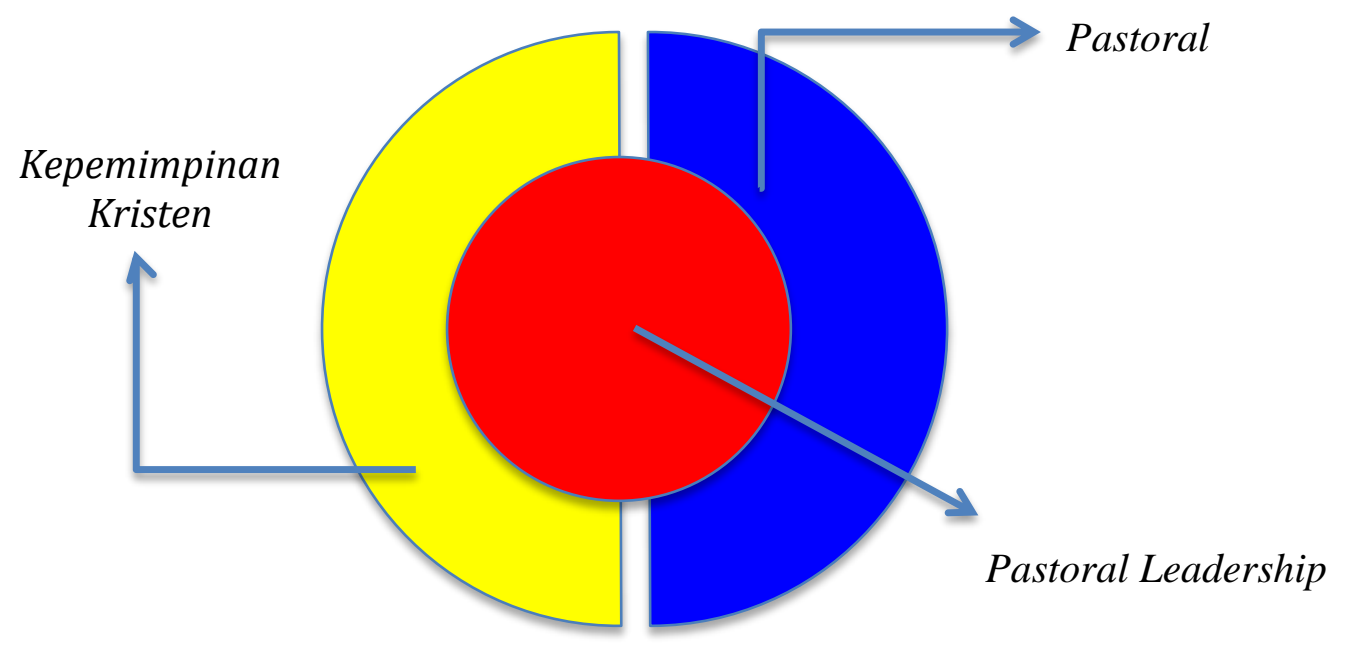

Bagan yang Menunjukkan Posisi yang sentral dari Pastoral Leadership dalam Kurikulum STT Pelita Dunia

Gambar di atas memberikan gambaran perihal hubungan ketiga mata kuliah: Kepemimpinan Kristen, Pastoral dan mata kuliah yang diusulkan untuk ditambahkan melalui penelitian ini, yakni: Pastoral Leadership. Berdasarkan gambar di atas memperlihatkan bahwa kepemimpinan Kristen dan Pastoral dikategorikan sebagai pengantar untuk masuk ke dalam pastoral leadership. Sehingga apabila tidak ditambahkan mata kuliah pastoral leadership, maka mahasiswa atau lulusan yang akan dihasilkan adalah lulusan yang mengerti ilmu kepemimpinan dan ilmu pastoral tetapi belum tentu memahami pastoral leadership. Padahal dalam konteks pelayanan gerejawi dan penggembalaan justru hal inilah yang paling diperlukan. 


\section{Penerapan Kepemimpinan Pastoral Yesus Dalam Kurikulum STT Pelita Dunia}

Pada bagian ini akan dikemukakan perihal bagaimana penerapan Pastoral Leadership Yesus dalam kurikulum STT Pelita Dunia. Berdasarkan rekomendasi dan usulan pada poin sebelumnya, maka perlu ditambahkan mata kuliah Pastoral Leadership pada kurikulum STT Pelita Dunia. Di mana konten mata kuliah ini didasarkan pada pastoral leadership Yesus seperti yang telah dibahas dalam Pastoral Leadership Yesus dalam Kitab Injil.

Macalinao memberikan tiga aspek penting dalam pastoral leadership, yakni: teori, skil dan isu. Artinya teori dan model kepemimpinan merupakan dasar untuk menyediakan kerangka kerja. Keterampilan dan hal-hal praktis kepemimpinan memberikan rincian kerangka kerja. Masalah kepemimpinan adalah tantangan yang mempertanyakan teori, model, keterampilan, dan hal-hal praktis agar kepemimpinan tetap relevan dan menjadi yang terdepan dalam pelayanan. ${ }^{30}$ Ketiga aspek inilah yang akan diakomodir dalam mata kuliah Pastoral Leadership yang diusulkan untuk ditambahkan dalam kurikulum STT Pelita Dunia. Supaya setiap alumni nantinya dapat mempraktikkan kepemimpinan gembala Yesus dalam setiap pelayanan dan penggembalaan yang dikerjakan.

Apabila memperhatikan pembahasan pada bagian sebelumnya, khususnya bagian tentang Pastoral Leadership Yesus dalam Kitab Injil, maka di sana diperoleh beberapa indikator, yakni: Pertama, pemimpin atau gembala melaksanakan pastoral leadership untuk menjalankan dan mengerjakan visi Allah. Kedua, pemimpin atau gembala melaksanakan pastoral leadership untuk menjangkau yang terhilang dan memperbaiki relasi dengan Allah. Ketiga, 
pemimpin atau gembala melaksanakan pastoral leadership untuk memuridkan dan mengutus. Apabila memperhatikan ketiga indikator di atas dan apabila menghubungkan kepada pendapat Macalinao maka dapat dilihat dalam pengelompokkan sebagai berikut:

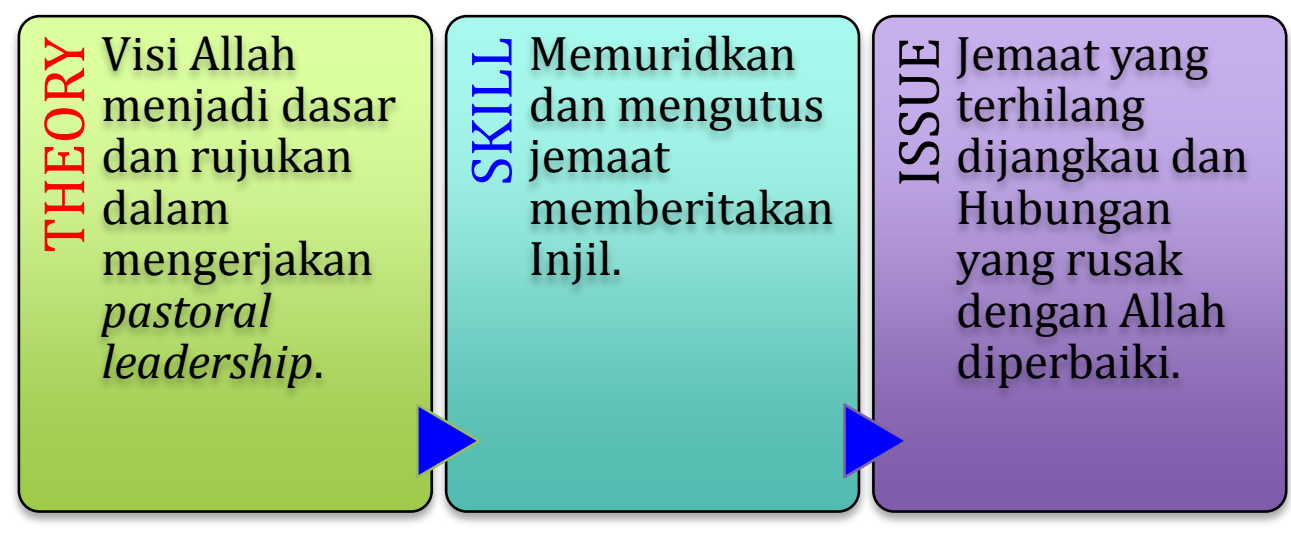

Bagan tentang Theory, Skill dan Issue yang disesuaikan dengan teori Macalinao

Dengan demikian, apabila mata kuliah Pastoral Leadership yang diusulkan dalam penelitian ini dapat diterapkan dalam kurikulum STT Pelita Dunia, maka akan menghasilkan alumni yang menjalankan visi Allah dalam pelayanan dan penggembalaan, alumni yang menjangkau jemaat yang terhilang, membawanya kembali ke dalam persekutuan, dan memperbaiki relasi mereka yang rusak karena dosa, dan alumni yang memuridkan jemaat dengan pengajaran Firman Tuhan yang benar dan alkitabiah guna mengerti dan memahami kehendak Allah dalam hidup mereka untuk selanjutnya diutus mengerjakan misi Allah dan memberitakan Injil Kristus.

Itulah sebabnya, mata kuliah Pastoral Leadership (2 sks) dapat dirinci Standar Kompetensi (SK), Kompetensi Dasar (KD) dan Urutan serta Rincian Materi, sebagai berikut: 
Standar Kompetensi (SK): Mahasiswa memiliki kemampuan dan keterampilan dalam pastoral leadership yang berdasarkan pastoral leadership Yesus Kristus dalam Alkitab.

Kompetensi Dasar (KD): Pertama, mampu menjelaskan pengertian kepemimpinan gembala (pastoral leadership), kedua, mampu menjelaskan dasar Alkitab pastoral leadership Yesus Kristus, ketiga, mampu mengidentifikasi polapola pastoral leadership Yesus Kristus, keempat, mampu mengemukakan visi Allah yang dikerjakan dalam pastoral leadership yang dikerjakan oleh Yesus Kristus, kelima, mampu menguraikan prinsip dan cara menjangkau dan menyelamatkan jemaat yang terhilang dan memperbaiki relasi dengan Allah dengan mengimitasi pola pastoral leadership Yesus Kristus, keenam, mampu mengidentifikasi problem-problem sosial dan moral yang muncul dalam jemaat untuk diperbaiki dalam pastoral leadership, ketujuh, mampu memahami aktivitas memuridkan seperti yang telah dilakukan oleh Yesus, kedelapan, mampu menjelaskan aktivitas mengutus seperti yang telah dilakukan oleh Yesus untuk diterapkan dalam pelayanan pastoral leadership yang dikerjakan, kesembilan, mampu menerapkan dan mendesain sebuah program pastoral leadership dalam jemaat untuk selanjutnya dipraktikkan dalam pelayanan dan penggembalaan.

Urutan dan Rincian Materi: pertama, definisi dan Pengertian Pastoral Leadership; kedua, dasar Alkitab Pastoral Leadership; ketiga, pola-pola dan Prinsip Pastoral Leadership Yesus Kristus; keempat, visi Allah dalam Pelaksanaan dan Penerapan Pastoral Leadership; kelima, isu dalam Pastoral Leadership: Menjangkau yang Terhilang dan Memperbaiki Relasi yang Rusak dengan Allah; dan keenam, skill Pastoral Leadership: Memuridkan dan Mengutus. 


\section{KESIMPULAN}

Setelah menguraikan topik ini dengan panjang-lebar, maka diberikan beberapa kesimpulan, sebagai berikut: Pertama, Pastoral leadership Yesus berdasarkan penjelasan dalam Injil terlihat dengan jelas dalam tiga hal, seperti: pastoral leadership Yesus menjalankan visi Allah dan itu artinya setiap gembala juga menjalankan visi Allah, pastoral leadership Yesus menjangkau yang hilang dan memperbaiki relasi dan itu artnya setiap gembala juga menjangkau jemaat yang terhilang dan memperbaiki relasi yang rusak dengan Allah, serta pastoral leadership Yesus memuridkan dan mengutus dan itu artinya setiap gembala memuridkan dan mengutus jemaat untuk memberitakan Injil. Kedua, untuk dapat menghasilkan lulusan yang mengerti pastoral leadership seperti yang dilakukan oleh Yesus, maka pada kurikulum STT Pelita Dunia perlu menambahkan mata kuliah Pastoral Leadership. Sekalipun dalam kurikulum STT Pelita Dunia yang masih mengacu kepada buku kuning dari Direktorat Bimas Kristen (DBK) sudah terdapat mata kuliah Kepemimpinan Kristen dan Pastoral namun belum cukup, sehingga perlu ditambahkan mata kuliah Pastoral Leadership. Ketiga, mata kuliah Kepemimpinan Kristen dan Pastoral dalam kurikulum STT Pelita Dunia dapat dikategorikan ke dalam mata kuliah pengantar untuk masuk ke dalam mata kuliah Pastoral Leadership. Sehingga setiap mahasiswa yang hendak mengambil mata kuliah Pastoral Leadership sudah harus mengambil dua mata kuliah tersebut. Diharapkan setiap lulusan yang telah mengambil mata kuliah Pastoral Leadership dapat memahami pastoral leadership Yesus untuk selanjutnya diterapkan dalam pelayanan dan penggembalaan yang dikerjakan. 


\section{DAFTAR PUSTAKA}

Christine, David Wayne. "Baptist Pastoral Leadership: An Analysis for Curriculum Development." University of North Texas, 2010.

Creswell, John. Riset Pendidikan: Perencanaan, Pelaksanaan, dan Evaluasi Riset Kualitatif dan Kuantitatif. Edisi Keli. Yogyakarta: Pustaka Pelajar, 2015.

D.A. Carson, R.T. France, J.A. Motyer, dan G.J. Wenham., ed. Tafsiran Alkitab Abad Ke-21 (Matius-Wahyu). Jakarta: YKBK/OMF, 2017.

Fallo, Fenci. Apa itu pastoral leadership? Alumni STT Pelita Dunia, 19 Januari 2021.

Given, Lisa M., ed. The SAGE Encyclopedia of Qualitative Research Methods Volume 1 \& 2. New Delhi, India: SAGE Publication, 2008.

Greenleaf, Robert. The Power of Servant Leadership. San Francisco: CA. BerrettKoehler Publications Inc., 1998.

Kruse, Colin G. The Tyndale New Testament Commentaries: John. Surabaya: Momentum, 2007.

Laia, Kasiria. Apa itu pastoral leadership? Alumni STT Pelita Dunia, 19 Januari 2021.

Leavy, Patricia, ed. The Oxford Handbook of Qualitative Research. New York: Oxford University Press, 2014.

Macalinao, Romerlito C. "Study of The Leadership Attributes of Pastors In Large Churches In Urban Metro Manila and The Implications to Designing A Pastoral Leadership Development Program." ASIA GRADUATE SCHOOL OF THEOLOGY, 2004.

Morris, Leon. Tafsiran Injil Matius. Surabaya: Momentum, 2016.

- The Tyndale New Testament Commentaries: Luke. Surabaya: Momentum, 2007.

Panduan Kurikulum Stratum Satu (S1) Prodi Teologi Kependetaan STT dan STAK di Indonesia. Jakarta: Direktorat Jenderal Bimbingan Masyarakat Kristen, Kementerian Agama RI, 2011.

Panjaitan, Juliana. "Pengaruh kepemimpinan Gembala sidang terhadap pertumbuhan gereja masa kini,” 2020.

Parapat, Yohanes. "Fungsi Gembala Jemaat dalam Suksesi-Refleksi atas Kepemimpinan Yesus pada Model Gereja Otonomi." HARVESTER: Jurnal Teologi dan Kepemimpinan Kristen 5, no. 2 (2020): 73-85. https://doi.org/10.52104/harvester.v5i2.43 
Prajogo, Natanael S. "Implementasi kepemimpinan gembala yang melayani berdasarkan 1 Petrus 5: 2-10 di kalangan gembala jemaat Gereja Bethel Indonesia se-Jawa Tengah." Harvester: Jurnal Teologi dan Kepemimpinan Kristen 4, no. 1 (2019): 1-21. https://doi.org/10.52104/harvester.v4i1.5

Purwanto, Agus. "Kepemimpinan Yesus Kristus sebagai Model Kepemimpinan Kristen." Mathetes: Jurnal Teologi dan Pendidikan Kristen 1, no. 2 (2020): 131-46. https://sttbethelsamarinda.ac.id/ejournal/index.php/mathetes/article/view/17/18

R. Boiliu, Esti. Apa itu pastoral leadership? Alumni STT Pelita Dunia, 19 Januari 2021.

Rumlawang, Fridolin. Apa itu pastoral leadership? Alumni STT Pelita Dunia, 19 Januari 2021.

Telaumbanua, Elvis. Apa itu pastoral leadership? Alumni STT Pelita Dunia, 19 Januari 2021.

Wakkary, Adriaan. "Kepemimpinan Yesus.” Rhema: Jurnal Teologi Biblika dan Praktika 3, no. 2017$). \quad$ https://e-journal.sttyestoya.ac.id/index.php/rhema/article/view/40/28 